\title{
Estudio de una moneda de Jaime I hallada en el "Vall Vell" de Valencia
}

\author{
Vicente Falcó Fuertes *
}

\section{DESCRIPCIÓN}

DINERO DE "DOBLENC" DE JAIME I ( 12 I31276)

ANV.I: BARQINO. Escudo real de Aragón de tres palos.

REV./: IACOB'REX. Cruz interior.

CECA: BARCELONA

FECHA EMISIÓN : año 1222

METAL: VELLÓN (2 dineros de ley)

CONSERVACIÓN: ALGO GASTADA

PESO: 0,90 grs.

DIÁMETRO: $17,00 \mathrm{~mm}$.

GROSOR: $1,00 \mathrm{~mm}$.

POSICIÓN DE CUÑOS: I I h.

REFa CATÁLOGO: BOTET-I63b. CRUSA-

FONT I5 I-I.

GRADO DE RAREZA: E (escasa)

\section{COMENTARIO}

Por lo general el hallazgo de una moneda aislada no supone una gran importancia, pero el hecho de que ésta proceda de una excavación arqueológica hace que su recuperación adquiera un valor cronológico muy importante.

La presencia estratigráfica de esta moneda (Lámina I) hallada en las excavaciones realizadas en el "Vall Vell" de Valencia podría resultar deci- siva a la hora de establecer la cronología del horizonte en que se agrupa su hallazgo (segunda mitad del siglo XIII) si tenemos en cuenta las características de circulación y pervivencia propias de la misma.

Su identificación no ofrece ninguna dificultad ya que disponemos de trabajos bien documentados como el de J. Botet i Sisó: "Les monedes catalanes" Barcelona 1908-12 y el del profesor Philip Grierson sobre los orígenes de este tipo de moneda "Notes sobre les primeres amonedacions reials a Barcelona: els termes Bruneti, Bossonaya i el Chronicon Barcinonense", presentado en el Symposium Numismático de Barcelona de 1979, en el que se aclaran algunas cuestiones confusas sobre fecha de emisión y metrología de los dineros de vellón ("doblenc") emitidos en Barcelona por Jaime I (12 |3- | 276).

Solo se conocen dos tipos distintos de dineros de vellón acuñados en Barcelona con el nombre de Jaime I: los dineros de "doblenc" de 1222 a 1258 y los dineros de "tern" de 1258 a 1276. Los dineros que llevan el escudo heráldico son los de doblenc y los que llevan el busto real son los de tern.

La moneda en estudio pertenece a las primeras. El año de su emisión es el 1222 en que sustituyen a las emisiones de Pedro I (11961213) padre del rey Jaime I. El año 1222 nos proporciona el terminus post quem de este

* Avda. Agricultor n 22, 2 A 12600 Vall de Uxo, (Castellón). 
hallazgo. Lo interesante sería conocer el tiempo transcurrido hasta que dejó de circular y quedó perdida o enterrada.

La moneda de doblenc o duplo toma su nombre porque se mezclaban dos marcos de plata en los doce de que se formaba el riel para acuñarla, siendo su ley de dos dineros ( $16 \%$ de AR.)

La "Ley" o cantidad de metal noble, era fijada por el rey, el cual se comprometía a no alterarla a cambio de recibir el "morabeti", tributo del monedaje, que se pagaba cada siete años, equivalente al de la "moneda forera" de Castilla.

El sistema de cuenta monetaria durante Jaime I en todos sus estados es el compuesto por la "Lliura" (moneda imaginaria) dividida en 20 "Sous" o sueldos; cada "sou" equivalía a 12 dineros de vellón.

Por cada marco de plata se tallaban 107 sous 6 1/2 dineros de doblenc. El marco de Barcelona pesaba 234,27 grs. con lo que el peso teórico de un dinero de doblenc es de 1,09 grs. del que 0,18 grs. eran de plata.

El dinero hallado en el "Vall Vell" de Valencia pesa 0,90 grs., su diferencia con el peso teórico es de 0,19 grs., lo que hipotéticamente puede representar el desgaste sufrido en unos 44 años $(0,19$ grs. / 0,0043 grs de desgaste anual $=44$ años) que añadidos al año de acuñación (I 222) nos daría un margen bastante aceptable para datar su perdida.

Por otra parte la política monetaria de Jaime I estuvo dirigida a lograr la unificación entre las distintas especies de vellón de sus estados: Aragón, Cataluña, Valencia o Mallorca.

Tras la Conquista de Valencia ( 1238 ) Jaime I crea en el año 1247 la moneda propia del Reino de Valencia, la denominada "Reals de Valencia" con el busto del monarca coronado en el anverso y el "arbor ad modum floris" en el reverso. La ley que se establece para estas monedas es la de terno o "tern" (tres dineros de plata y nueve de cobre en cada sueldo) igual a 250 milésimas; similar a los dineros de Aragón de 1236.

Cuando se crea la moneda de Valencia circulaban en Cataluña los dineros barceloneses de doblenc, confirmados en I 254 por Jaime I bajo juramento de no alterarlos. Sin embargo en I 257 dicho rey solicita y recibe del Papa Alejandro IV la absolución a su juramento, creando al año siguiente ( 1258 ) la moneda barcelonesa de tern, semejante a la moneda valenciana en ley; comprometiéndose a no alterarla de nuevo y renunciando al impuesto del monedaje. Se llega pues en 1258 a la unificación monetaria dentro del ciclo del dinero de vellón. El diner de tern circulaba en Cataluña, Aragón, Valencia y Mallorca con tipos distintos, pero con valor análogo.

El cambio de la moneda vieja (de doblenc) por la nueva (de tern) se fija en 1259 a razón de: tres sueldos de la de doblenc valdrían dos sueldos de la de tern.

También en Valencia al crearse los "Reals de Valencia", única moneda que debía circular en los reinos de Valencia y Mallorca, se creó la "Taula" de cambio, en la que debían cambiarse todas las monedas en circulación por la nueva. Por la relación de las equivalencias de la "Taula" conocemos las monedas que circulaban entonces en Valencia y el tipo de cambio a que fueron sometidos los dineros barceloneses de doblenc (I 8 Dineros Barceloneses $=12$ Reals de Valencia).

Por todo lo expuesto, es de suponer que los dineros barceloneses de doblenc de Jaime I quedarían desmonetizados y totalmente sustituidos por los dineros de tern, no más allá del tercer cuarto de siglo.

Este dato parecen confirmarlo también los hallazgos de tesoros de monedas de vellón en tierras valencianas (Castell de Chio, Llutxent, 1930; Almenara-Benavites, 1929; Castell de La Reina Mora, Benifairó de la Valldigna, 1953) fechados a finales del reinado de Jaime I y en los que solamente aparecen junto a los "Reals de Valencia" los Dineros Barceloneses de tern emitidos por Jaime I en 1258, que desplazarían de la circulación monetaria a los dineros de doblenc. 


\section{BIBLIOGRAFÍA}

BELTRÁN, P. (1972): "Los dineros jaqueses, su evolución y desaparición". En Obra Completa. Zaragoza.

BOTET, J. (1908): Les monedes catalanes. Barcelona.

CRUSAFONT, M. (1982): Numismática de la Corona Catalano-aragonesa medieval (785-15/6). Madrid.

GRIERSON, Ph. (1979): "Notes sobre les primeres amonedacions reials a Barcelona: els termes Bruneti, Bossonaya i el Chronicon Barcinonense". Symposium Numismático de Barcelona A.N.E. 1979.
FALCÓ, V. (1986): Estudio numismático sobre la moneda valenciana del Museo Histórico Municipal de Burriana. Col.leccio Papers del Departament d'Investigació Histórica del Museu Arqueològic. Borriana.

MATEU, F. (1929): La ceca de Valencia y las acuñaciones valencianas de los siglos XIII al XVIII. Valencia.

RIPOLLÉS, P. P.; LLORENS, M. (1990): "El tresor de La Reina Mora: monedes de Jaume I". Acta Numismática. Barcelona. 